\title{
Species-area relationships for coral reef fish assemblages of St. Croix, US Virgin Islands
}

\author{
Paul M. Chittaro* \\ University of Windsor, Department of Biological Sciences, Windsor, Ontario N9B 3P4, Canada
}

\begin{abstract}
Since the early 1920s, ecologists studying a variety of taxa have observed a positive relationship between the number of species and area sampled. The purpose of this study was to examine species-area relationships in coral reef fish assemblages in a tropical marine ecosystem and to determine what factors influence this relationship on isolated patch and continuous reefs. A positive relationship between the log (species richness of reef fish) and log (coral reef area) was observed, where area explained 66 to $96 \%$ of the variation in species richness. At smaller spatial scales patch reefs contained significantly more, approximately $35 \%$ more, species than continuous reefs. However, the slope was significantly greater for continuous reefs, and consequently at larger spatial scales the number of species was similar to that of patch reefs. Explanations are given for the observed variation between the slopes of species-area curves reported here and those of other studies. These include an influence from the 3-dimensional nature of reef systems, the lack of quantification at sufficient spatial scales and the potential role of habitat richness. Multiple forward stepwise regressions indicated that $80.2 \%$ of the variation in species richness on continuous reefs was explained by a suite of microhabitat variables, whereas for patch reefs only $55.7 \%$ of the variation was explained by these same variables. Of the variables, microhabitat richness was found to explain the greatest amount of variation in species richness for both continuous and patch reefs even though the species-area relationships differed significantly.
\end{abstract}

KEY WORDS: Species-area relationship $\cdot$ Reef fish

Resale or republication not permitted without written consent of the publisher

\section{INTRODUCTION}

Ecologists historically have been interested in understanding how the spatial extent of the environment can influence community structure. In fact, one of the longest standing mathematical relationships described in ecology is that which relates species richness to area (Arrhenius 1921, Gleason 1922, Connor \& McCoy 1979, McGuinness 1984, Palmer \& White 1994). This relationship has been called the 'most profound empirical observation in ecology ... no relationship is more informative for understanding how communities are organised' (Durrett \& Levin 1996, p. 119). Over the years several hypotheses have been proposed to ex-

*E-mail: chitta1@uwindsor.ca plain the species-area relationship. The random placement hypothesis suggests that as the area sampled increases there is a concomitant increase in numbers of individuals and consequently an increase in species sampled (Hart \& Horwitz 1991). This increase in species is viewed as being random, an artifact of an increasing sample size (Roberts \& Ormond 1987). The equilibrium theory of island biogeography states that the number of species on an island is related to the island's distance from the source pool of new recruits and its immigration and extinction rates, which are dependant upon the size of the island (MacArthur \& Wilson 1967, Simberloff 1976). If distance from the source pool is constant, then smaller islands will have a greater extinction rate, lower immigration rate and therefore fewer species (Abele \& Patton 1976, Simberloff 1976, Schoener \& Schoener 1981). Finally, the 
habitat diversity hypothesis argues that the number of species is greater in larger areas because of a related increase in the richness of habitat, which in turn allows colonization of different species (Connor \& McCoy 1979).

Since the early 1920 s countless studies on a diversity of taxa, plants (Chemengich 1993, Buys et al. 1994, Chiarucci 1996, Singh et al. 1996, Falkner \& Stohlgren 1997, Morrison 1997, Stohlgren et al. 1997, Lawesson et al. 1998), invertebrates (Peake \& Quinn 1993, Santelices et al. 1995, Gasnier et al. 1997, Anderson 1998, Baldi \& Kisbenedek 1999), birds (Androukaki \& Adamantopoulou 1992, Johnson \& Patil 1995, Falkner \& Stohlegren 1997), mammals (Danell et al. 1996, Falkner \& Stohlegren 1997) and fish (Angermerier \& Schlosser 1989, Oberdorff et al. 1995) have explored the species-area relationship in order to characterize

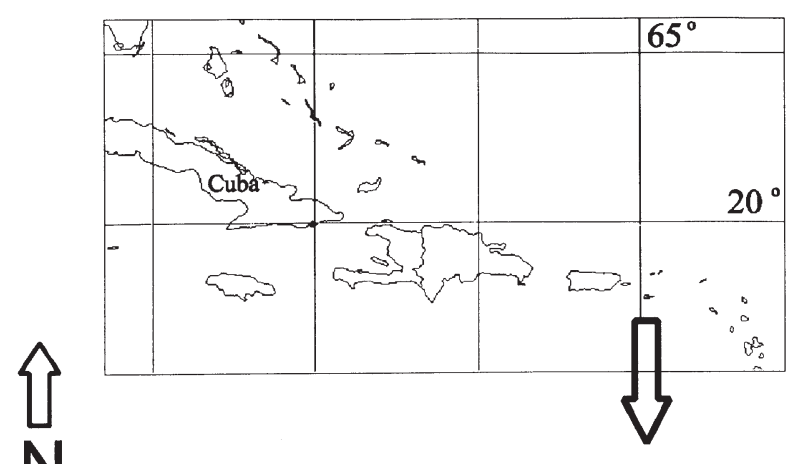

$\mathrm{N}$
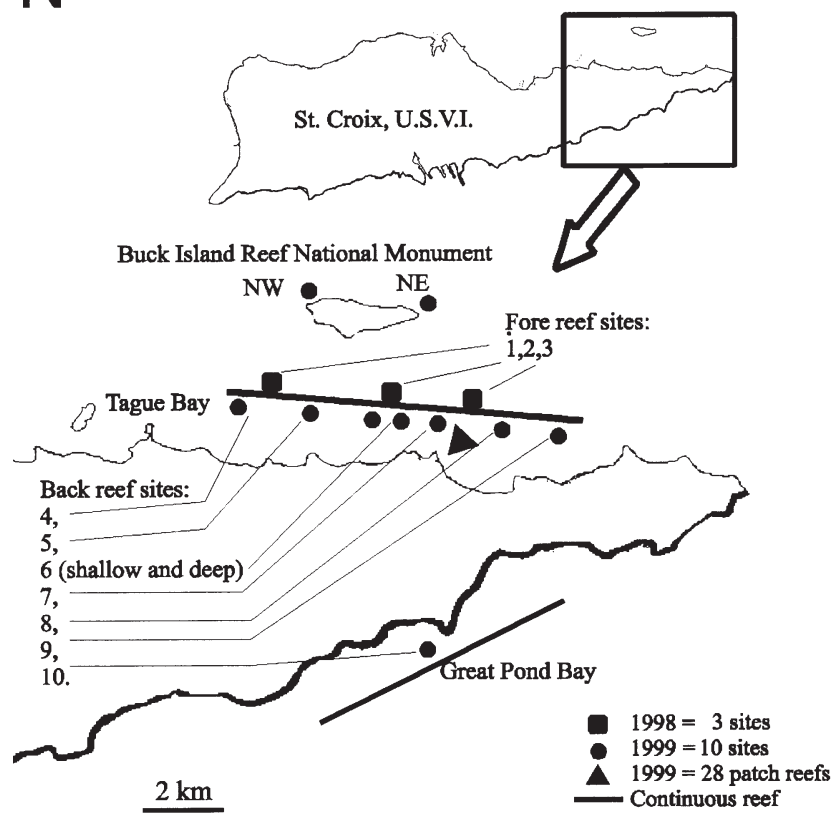

Fig. 1. Representation of sites around St. Croix and Buck Island Reef National Monument, US Virgin Islands (USVI) assemblages, determine the area needed to adequately sample a desired suite of species, estimate species richness, investigate the effects of disturbance, and define the appropriate size of reserves and natural areas (He \& Legendre 1996, Connor \& McCoy 1979). Unfortunately, investigations of fish species-area relationships, particularly reef fish, are generally absent from the literature. Only 2 species-area relationships for freshwater fish systems exist in the literature (Angermeirer \& Schlosser 1989, Oberdorff et al. 1995), whereas only circumstantial evidence for such a relationship exists in coral reef fish systems (Bell \& Galzin 1984, McClanahan 1994). By understanding how area might influence the structure of reef fish assemblages, fisheries managers, for instance, gain valuable information that would aid in the protection of these resources through the establishment of marine protected areas (Jones \& Syms 1998). Specifically, knowledge about reef fish species-area relationships could be used to address the mechanisms structuring fish communities and the area needed to completely sample an assemblage and effectively protect it.

The purpose of this study was to explore reef fish species-area relationships of St. Croix and Buck Island Reef National Monument (BIRNM), US Virgin Islands. Comparisons of species-area relationships are drawn between patch and continuous reefs and the effects of various habitat attributes (i.e. habitat-diversity hypothesis) in contributing to these relationships were examined.

\section{MATERIALS AND METHODS}

Field work was conducted around St. Croix and BIRNM, US Virgin Islands, from May 15 to August 15, 1998 and 1999. During these periods, 13 sites were randomly established on sections of continuous reef. Ten sites were within Tague Bay, 1 was at Great Pond Bay, and 2 were at BIRNM (USNPS permit \# 99005) (Fig. 1). A set of 28 patch reefs also was censused within the lagoon of Tague Bay during 1999. Unlike sites on the continuous reef (i.e. Tague Bay and Great Pond Bay), patch reefs were isolated structures, surrounded by $\geq 5 \mathrm{~m}$ of non-reef habitat. Three Tague Bay fore-reef sites (1, 2 and 3 ) and 1 back-reef site (6 deep), as well as 1 at BIRNM (northeast) were $3 \mathrm{~m}$ deep in water, whereas the remaining sites were $\leq 1.5 \mathrm{~m}$ deep.

At each site on the continuous reef, species composition and abundance were recorded while swimming (SCUBA or snorkeling) along linear transects set parallel to the reef crest. At each site these reef fish assemblage attributes were quantified by placing polyvinyl chloride (PVC) measuring tapes at 4 transect lengths $(1,10,100$ and $200 \mathrm{~m})$. These transects were censused 
Table 1. Summary of site replicates and linear regression models of species-area relationships. All regressions were significant at $\mathrm{p}<0.01$. A: Area; BIRNM: Buck Island Reef National Monument; Sp: Species number; z: slope of regression

\begin{tabular}{|c|c|c|c|c|c|c|c|c|c|c|c|c|c|}
\hline \multirow[t]{2}{*}{ Location } & \multirow{2}{*}{$\begin{array}{c}\text { Fore/back } \\
\text { reef }\end{array}$} & \multirow[t]{2}{*}{ Site } & \multirow[t]{2}{*}{ Year } & \multicolumn{4}{|c|}{ - Number of replicates - } & \multicolumn{3}{|c|}{$-\log \mathrm{Sp}-\log \mathrm{A}-$} & \multirow{2}{*}{$\begin{array}{c}\text { Sp-A } \\
r^{2}\end{array}$} & \multirow{2}{*}{$\begin{array}{c}\log \\
\mathrm{Sp}-\mathrm{A} \\
\mathrm{r}^{2}\end{array}$} & \multirow{2}{*}{$\begin{array}{c}\text { Sp-log A } \\
r^{2}\end{array}$} \\
\hline & & & & $1 \mathrm{~m}^{2}$ & $10 \mathrm{~m}^{2}$ & $100 \mathrm{~m}^{2}$ & $200 \mathrm{~m}^{2}$ & ${ }^{2}$ Intercept & $z$ & $\mathrm{r}^{2}$ & & & \\
\hline Tague Bay & Fore & 1 & 1998 & 10 & 7 & 1 & & 0.69 & 0.47 & $0.89^{\mathrm{a}}$ & 0.85 & 0.48 & 0.86 \\
\hline Tague Bay & Fore & 2 & 1998 & 10 & 7 & 1 & & 0.63 & 0.42 & 0.86 & $0.90^{\mathrm{a}}$ & 0.56 & 0.76 \\
\hline Tague Bay & Fore & 3 & 1998 & 10 & 7 & 1 & & 0.68 & 0.43 & $0.89^{\mathrm{a}}$ & 0.71 & 0.47 & 0.83 \\
\hline Tague Bay & Back & 4 & 1999 & 20 & 20 & 10 & 10 & 0.59 & 0.43 & $0.92^{\mathrm{a}}$ & 0.82 & 0.58 & 0.89 \\
\hline Tague Bay & Back & 5 & 1999 & 20 & 20 & 10 & 10 & 0.43 & 0.48 & $0.86^{\mathrm{a}}$ & 0.83 & 0.58 & 0.82 \\
\hline Tague Bay & Back & 6 deep & 1999 & 20 & 20 & 10 & 10 & 0.57 & 0.49 & $0.89^{\mathrm{a}}$ & 0.88 & 0.67 & 0.86 \\
\hline Tague Bay & Back & 6 shallow & 1999 & 20 & 20 & 10 & 10 & 0.43 & 0.48 & $0.92^{\mathrm{a}}$ & 0.86 & 0.69 & 0.82 \\
\hline Tague Bay & Back & 7 & 1999 & 20 & 20 & 10 & 10 & 0.54 & 0.45 & $0.92^{\mathrm{a}}$ & 0.88 & 0.68 & 0.84 \\
\hline Tague Bay & Back & 8 & 1999 & 20 & 20 & 10 & 10 & 0.64 & 0.42 & $0.95^{\mathrm{a}}$ & 0.93 & 0.76 & 0.87 \\
\hline Tague Bay & Back & 9 & 1999 & 20 & 20 & 10 & 10 & 0.39 & 0.52 & $0.88^{\mathrm{a}}$ & 0.87 & 0.69 & 0.84 \\
\hline Tague Bay & Patch reef & & 1999 & & $\begin{array}{l}\text { tches ra } \\
\text { from } 0\end{array}$ & $\begin{array}{l}\text { anging in } \\
0.6 \text { to } 64\end{array}$ & $\begin{array}{l}n \text { size } \\
\mathrm{m}^{2}\end{array}$ & 1.03 & 0.24 & $0.66^{\mathrm{a}}$ & 0.50 & 0.46 & 0.64 \\
\hline Great Pond Bay & ay Back & 10 & 1999 & 10 & 10 & 10 & 5 & 0.68 & 0.39 & 0.84 & 0.84 & 0.63 & $0.88^{\mathrm{a}}$ \\
\hline BIRNM & Back $\mathrm{I}$ & Northeast & 1999 & 10 & 10 & 10 & 7 & 0.45 & 0.45 & $0.96^{a}$ & 0.90 & 0.78 & 0.87 \\
\hline BIRNM & Back $N$ & Northwest & 1999 & 10 & 10 & 10 & 5 & 0.60 & 0.38 & $0.84^{\mathrm{a}}$ & 0.76 & 0.66 & 0.80 \\
\hline Average & & & & & & & & 0.60 & 0.43 & 0.88 & 0.82 & 0.62 & 0.83 \\
\hline
\end{tabular}

at widths of $1 \mathrm{~m}$, which resulted in areas of $1,10,100$ and $200 \mathrm{~m}^{2}$. However, due to limitations of censusing time at depth, the 3 fore-reef sites were only sampled at 1, 10 and $100 \mathrm{~m}^{2}$ areas. Where possible, each spatial scale was replicated the same number of times for each site (Table 1).

Following fish quantification, the transect was reswum to record habitat type. Every $0.25 \mathrm{~m}$ along each transect, habitat observations were taken. Thus, 4, 40, 400 and 800 observations were taken for each 1, 10, 100 and $200 \mathrm{~m}^{2}$ transect, respectively. Each point was categorized by microhabitat (21 types) and algae/seagrass (11 types) communities, as well as structural and topographic complexity. The categories for both microhabitat and algae/seagrass types were determined through preliminary censuses at each site. Microhabitat types consisted of 21 different categories, which included species of coral (designated as living or dead) and substrates, such as pavement, sand and small rubble. Algae/seagrass types referred to 10 species of algae or seagrass and an 11th category in which no algae were present. Once these data were collected, the relative abundances of each microhabitat and algae/seagrass type were determined for each transect. Structural complexity was an index that measured the number of times an imaginary vertical line through a point on the transect (every $0.25 \mathrm{~m}$ ) passed from water to coral and back to water (Caselle \& Warner 1996). A value of 0 meant that there was no structural complexity; the greater the number the more complex the point. Topographic complexity was another index used to measure substratum complexity. It was determined by the ratio between a nylon line (1 m long) made to fit the contour of the substratum and the linear distance over this contour. A value of 1 meant that the substratum was planar, while increasing values indicate increasing substratum complexity.

In the lagoon of Tague Bay, 28 patch reefs that ranged in size from 0.6 to $64 \mathrm{~m}^{2}$ were also censused. Since patch reefs were not perfectly rectangular in shape, 2 transects (that also were censused at $1 \mathrm{~m}$ widths) were placed perpendicular to each other so that at least one of these transects was along the reef's longest dimension. Ellipses were then used to estimate the area of these patches $(\pi \times 0.5 \times$ longest transect $\times$ $0.5 \times$ shortest transect). Along these transects, reef fish species were recorded, as were the habitat measures.

Species-area analysis. A primary interest when examining species-area relationships is the formula that best describes the data (Baldi \& Kisbenedek 1999). Therefore, for all sites and patch reefs, species richness was determined at each spatial scale and regressed against area using 4 different models: (1) untransformed species richness and area; (2) $\log _{10}$ species richness and $\log _{10}$ area; (3) $\log _{10}$ species richness and area; and (4) species richness and $\log _{10}$ area. All patch reefs were used to form a single species-area curve since they were within the lagoon of Tague Bay. For $\log _{10}$ species plots, a constant of 1 was added to all counts to allow for the logarithm of 0 species present. The model that yielded the greatest coefficient of determination was deemed the best fit to the data. To investigate whether the addition of larger censused areas significantly altered the slopes of these curves, 


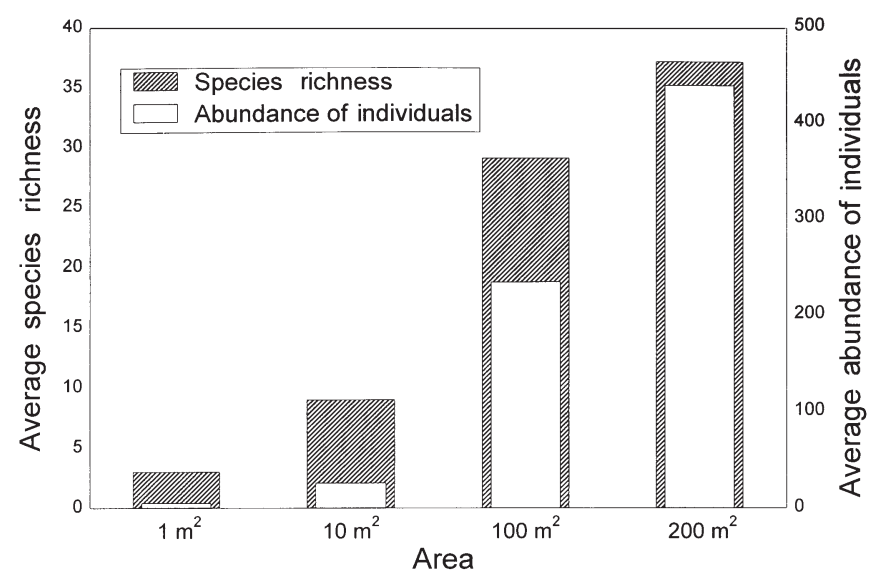

Fig. 2. Average species richness and abundance of individuals censused within each spatial scale $\left(1,10,100\right.$ and $\left.200 \mathrm{~m}^{2}\right)$ and across all sites

randomly selected replicates of 100 and $200 \mathrm{~m}^{2}$ (for only continuous reef sites) were pooled. This pooling produced areas of $1000,2000,3000,4000$ and $5000 \mathrm{~m}^{2}$. The slopes of the species-area curves produced from the pooling of replicates were compared to the original data set using a $t$-test (Zar 1996).
Patch and continuous reef species-area relationships. To determine whether species-area curves of continuous reefs, produced from pooling 7 Tague Bay back reef sites, and patch reefs were the same, a $t$-test was performed on their slopes and intercepts (Zar 1996). Regressions of microhabitat and algae/seagrass against area, for patch and continuous reefs, were used to understand how habitat structure varies among reef type. Prior to any analysis, algae/seagrass richness, microhabitat richness, topographic complexity and structural complexity were $\log _{10}$ transformed whereas the proportional abundances of microhabitat and algae/seagrass variables were arc sine transformed in order to improve normality.

Owing to the large habitat data set, which comprised 21 and 11 categories of microhabitat and algae/seagrass types, respectively, as well as structural and topographic complexity, the number of variables in the examination was reduced using principal component analysis (PCA) before building multiple regression models. Following PCA, a varimax orthogonal rotation of the principal components was conducted to improve the interpretation of the ordination diagram. Varimax rotation was used because it simpli-
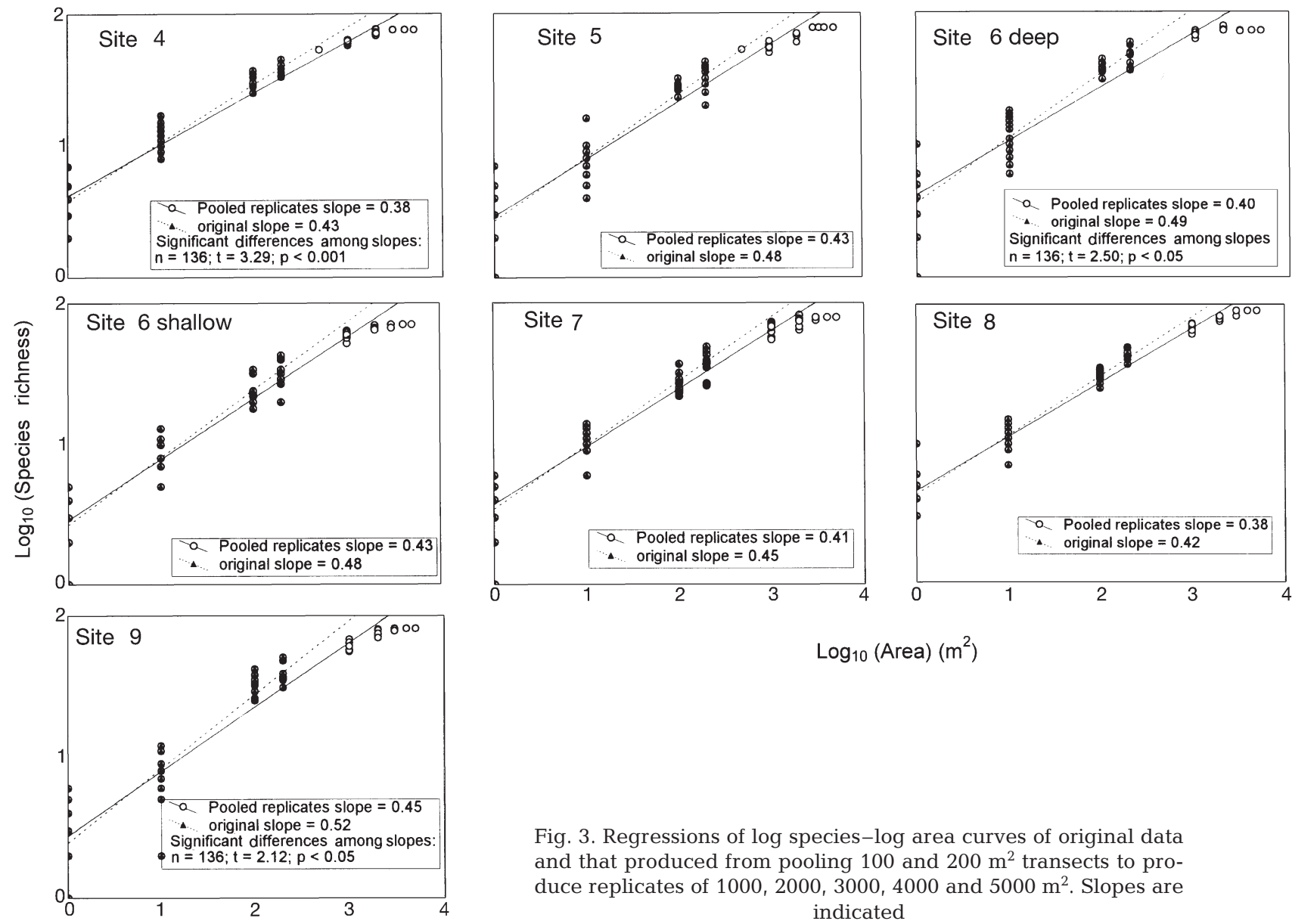

$\log _{10}\left(\right.$ Area) $\left(m^{2}\right)$

Fig. 3. Regressions of log species-log area curves of original data and that produced from pooling 100 and $200 \mathrm{~m}^{2}$ transects to produce replicates of 1000, 2000, 3000, 4000 and $5000 \mathrm{~m}^{2}$. Slopes are indicated 
fies principal components by maximizing the variances of the loadings within components (Statistica II 1995). To interpret a principal component, habitat variables with factor loadings $>10.3 \mid$ (which suggests a meaningful correlation, accounting for approximately $10 \%$ of the variation; Tabachnick \& Fidell 1996) were examined.

To investigate which habitat characteristics explained the greatest amount of variation in species richness on both continuous and patch reefs, separate multiple forward stepwise regressions were then conducted. For these multiple regression analyses, species richness was the dependant variable, and linear and non-linear (squared values) values of the principal components scores were the independent variables. Because of the quadratic forms

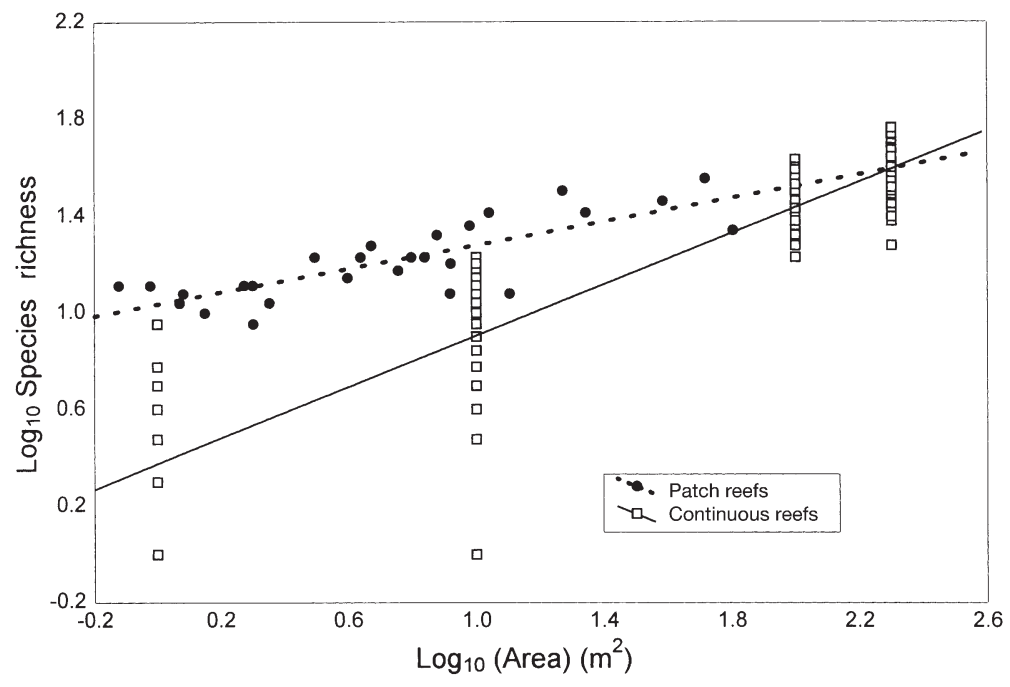

Fig. 4. Regressions of species-area relationships of pooled continuous reef sites ( 7 sites) and patch reefs (28 patch reefs) of Tague Bay

of the independent variables, non-linear relationships were examined. Multiple forward stepwise regression works by sequentially adding habitat variables to the regression equation only if there is significant improvement to the coefficient of determination (Jennings et al. 1996). Plots of residuals versus predicted values of $\log _{10}$ (species richness) were done following the analysis in order to test for normality, linearity and homoscedasticity (Tabachnick \& Fidell 1996).

\section{Patch and continuous reef species-area relationships}

The slope of the species-area curve for continuous back reef sites on Tague Bay was $46 \%$ greater ( $\mathrm{n}=444$, $t=7.72, \mathrm{p}<0.001$ ) than that for patch reefs (Fig. 4). However, the intercept of the patch reef curve was $35 \%$ greater $(\mathrm{n}=448, t=3172.8, \mathrm{p}<0.001)$ than that for continuous reef sites. These differences in slope could be attributed to the weak relationship between

\section{RESULTS}

More than $9 \mathrm{~km}^{2}$ of area was censused during the summers of 1998 and 1999, and a total of 87130 individuals, belonging to 118 species, were recorded (Fig. 2).

\section{Species-area analysis}

Simple linear regressions of all models $\left(\log _{10}\right.$ species- $\log _{10}$ area, $\log _{10}$ species area, species- $\log _{10}$ area, and species area) indicated strong positive relationships (Table 1). When replicates were pooled to form larger units (e.g. 1000, 2000, 3000, 4000 and $5000 \mathrm{~m}^{2}$ ), the slopes of the species-area curves decreased for each examined back reef site (Fig. 3), such that 3 sites showed a significant decrease (Site 4, $\mathrm{n}=136, t=3.29, \mathrm{p}<0.001$; Site 6 deep, $\mathrm{n}=$ 136, $t=2.50, \mathrm{p}<0.05$; and Site 9, $\mathrm{n}=136$, $t=2.12, \mathrm{p}<0.01)$.

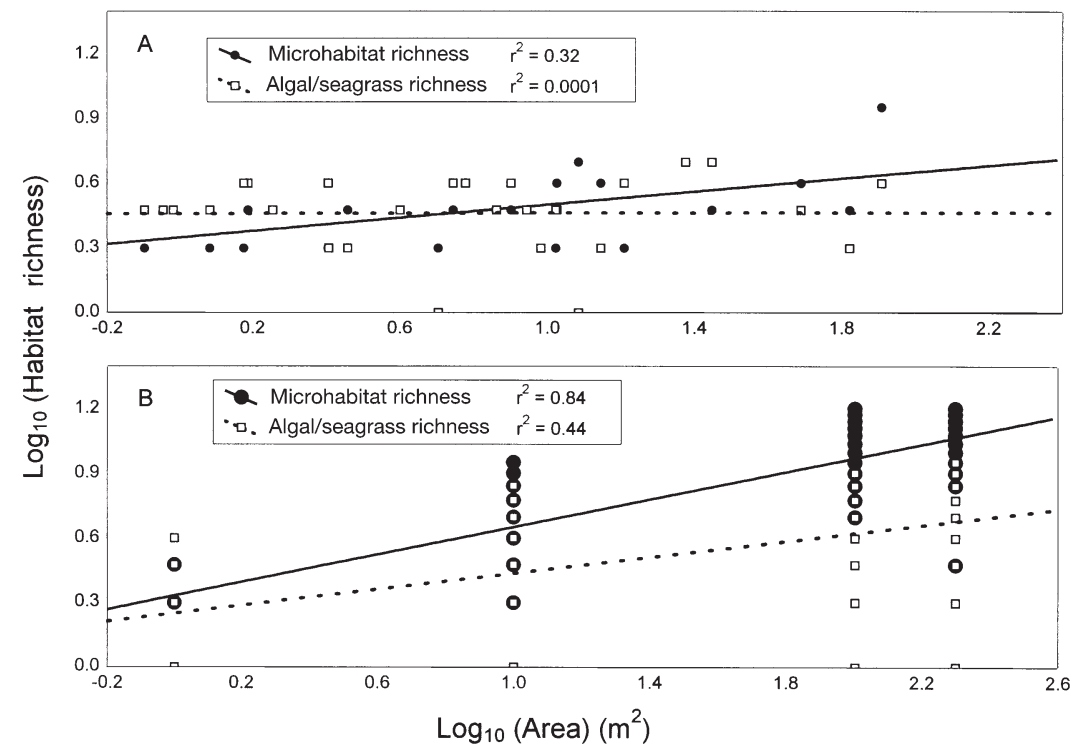

Fig. 5. Regressions of log microhabitat and algae/seagrass richness with respect to log area of (A) patch reefs and (B) continuous reefs of Tague Bay 
Table 2. Summary of multiple forward stepwise regressions that examined relationships between species richness and habitat variables for continuous and patch reefs. Habitat variables are listed in order of appearance in the regression. Their partial regression coefficients are shown with significance levels. Both linear and quadratic values of the habitat variables were used. F-stat indicates the overall significance of the regressions. (Refer to Table 3 for descriptions of principal components [PC]). ${ }^{*} \mathrm{p}<0.05{ }^{* *} \mathrm{p}<0.01 ;{ }^{* * *} \mathrm{p}<0.001$

\begin{tabular}{|c|c|c|c|c|}
\hline \multirow{2}{*}{$\begin{array}{l}\text { Reef type } \\
\text { Habitat variables } \\
\text { (relationship) }\end{array}$} & \multirow{2}{*}{$\begin{array}{l}\text { Slope } \\
\text { and } \\
\text { p-value }\end{array}$} & \multicolumn{3}{|c|}{$\begin{array}{l}\text { Significance of } \\
\text { regression analysis }\end{array}$} \\
\hline & & $\mathrm{df}^{\mathrm{a}}$ & $F$-stat & $\mathrm{r}^{2}$ \\
\hline Continuous reefs & & 11,408 & $150.18^{* * *}$ & 0.80 \\
\hline $\begin{array}{l}\text { Microhabitat } \\
\text { richness (linear) }\end{array}$ & $+^{* * *}$ & & & 0.73 \\
\hline $\begin{array}{l}\text { Algae/seagrass } \\
\text { richness (linear) }\end{array}$ & $++^{* * *}$ & & & 0.06 \\
\hline PC 1 (linear) & $+^{* *}$ & & & 0.004 \\
\hline $\begin{array}{l}\text { Microhabitat } \\
\text { richness (quadratic) }\end{array}$ & $++^{* *}$ & & & 0.004 \\
\hline PC 7 (linear) & $-^{*}$ & & & 0.003 \\
\hline PC 10 (linear) & $--^{*}$ & & & 0.003 \\
\hline PC 5 (linear) & $--^{*}$ & & & 0.003 \\
\hline PC 5 (quadratic) & $+^{*}$ & & & 0.002 \\
\hline PC 4 (quadratic) & $-^{*}$ & & & 0.002 \\
\hline PC 8 (linear) & $+^{*}$ & & & 0.002 \\
\hline PC 6 (linear) & $-^{*}$ & & & 0.002 \\
\hline Patch reefs & & 5,22 & $5.21^{* *}$ & 0.54 \\
\hline $\begin{array}{l}\text { Microhabitat } \\
\text { richness (linear) }\end{array}$ & $++^{* *}$ & & & 0.36 \\
\hline PC 7 (linear) & $-^{*}$ & & & 0.09 \\
\hline PC 5 (quadratic) & $+^{*}$ & & & 0.04 \\
\hline $\begin{array}{l}\text { Algae/seagrass } \\
\text { richness (linear) }\end{array}$ & $+^{*}$ & & & 0.02 \\
\hline PC 1 & $+^{*}$ & & & 0.02 \\
\hline a (regression, residual) & & & & \\
\hline
\end{tabular}

microhabitat (n = 1,26, $F=12.01, \mathrm{r}^{2}=0.32, \mathrm{p}<0.01$ ) and algae/seagrass ( $p>0.05$ ) richness on patch reef area (Fig. 5A), whereas both microhabitat ( $\mathrm{df}=1,525$, $\left.F=2841.3, \mathrm{r}^{2}=0.84, \mathrm{p}<0.001\right)$ and algae/seagrass (df $\left.=1,525, F=414.1, \mathrm{r}^{2}=0.44, \mathrm{p}<0.001\right)$ were strongly related to continuous reef area (Fig. 5B).

PCA on continuous reefs explained $62 \%$ of the variation in habitat variables (10 principal components), whereas $78 \%$ of the variation in habitat variables on patch reefs was explained by 7 components. Using these factors together with microhabitat and algae/seagrass richness, the multiple forward stepwise regressions explained $80.2 \%(\mathrm{df}=11,408, F=150.18, \mathrm{p}<0.001)$ and $55.7 \%(\mathrm{df}=5,22, F=5.54, \mathrm{p}<0.01)$ of the variation in species richness on continuous and patch reefs, respectively (Tables $2 \& 3$ ). Microhabitat richness was found to explain the majority of variance within both patch (36\%) and continuous $(73 \%)$ reefs. Following microhabitat richness, the stepwise regression indicated that, for continuous reefs, algae/seagrass richness explained an additional $6 \%$ of the variation in species richness followed by principal component $1(<1 \%)$, which was represented by complex substratum structures, and coral species Acropora palmata rubble and Agarcia agaricites live. For patch reefs, principal component 7 , represented by Porites porites live and Halimeda incrassata, explained an additional $9 \%$ of the variation in species richness, followed by principal component 5 (4\%), which was represented by $P$. porites live and several algae species, H. incrassata, Dictyota sp. and Udotea sp. Thus, variation in species richness was explained best by microhabitat richness for both reef types; however, the proportion explained for patch reefs was substantially less than that for continuous reefs.

\section{DISCUSSION}

The relative importance of area in determining the number of species present has been debated for over 80 years. Hypotheses that have been proposed to explain species-area relationships include the role of habitat heterogeneity (habitat diversity hypothesis; see Connor \& McCoy 1979), disturbance (see Hart \& Horwitz 1991), the distance to mainland together with immigration and extinction rates (theory of island biogeography; MacArthur \& Wilson 1967) and the influence of sampling (random placement hypothesis; see Connor \& McCoy 1979). According to Baldi \& Kisbenedek (1999), when examining species-area relationships, a main concern is the mathematical formula that best fits the data. In the present study, strong positive relationships between the numbers of reef fish species and coral reef area were observed, such that the power function model $\left(\log _{10}-\log _{10}\right.$ plot) best fit the species-area relationships for 12 out of 14 sites (Table 1). How do the species-area relationships from this study compare to others in the published literature? Unfortunately, few studies exist that examine these relationships in fish systems. Oberdorff et al. (1995) examined fish species-area relationships on a global scale and determined that the surface area of the drainage basin and mean annual discharge explained a significant amount of variation in species richness. Influential work by Preston (1962a, b), in which speciesarea relationships for several terrestrial taxa were determined, indicated that, on average, the slope of the curve (z-value) was 0.26. More recent work corroborates this by indicating slopes that range from 0.19 to 0.29 for plant communities (Western \& Ssemakula 1981, Buckley 1985, Dunn \& Loehle 1988, Nilsson et al. 1988, Rejmanek \& Rosen 1992, Singh et al. 1996); from 0.29 to 0.48 for invertebrate communities (Nilsson et al. 1988, Peake \& Quinn 1993); and from 0.18 to 0.25 for freshwater fish communities (Oberdorff et al. 1995). These slopes are substantially less, with the exception of some of the invertebrate work, than the mean value of 0.43 for contin- 
Table 3. Correlations of habitat variables with principal components (PC) from multiple regression models of continuous and patch reefs. Only habitat variables with correlations $>|0.3|$ were included in this table since these were regarded as being interpretable (Tabachnick \& Fidell 1996)

\begin{tabular}{|c|c|c|c|c|c|c|c|c|c|}
\hline \multirow{2}{*}{ Habitat variable } & \multirow[b]{2}{*}{ PC1 } & \multirow[b]{2}{*}{ PC4 } & \multicolumn{2}{|c|}{ Continuous reefs } & \multirow[b]{2}{*}{ PC8 } & \multirow[b]{2}{*}{ PC10 } & \multirow[b]{2}{*}{$\mathrm{PC} 1$} & \multirow{2}{*}{$\begin{array}{l}\text { Patch reefs } \\
\text { PC5 }\end{array}$} & \multirow[b]{2}{*}{ PC7 } \\
\hline & & & PC5 & PC7 & & & & & \\
\hline Acropora palmata dead & 0.4 & & & & & & & & \\
\hline Agarcia agaricites live & 0.4 & & & & & & & & \\
\hline Diploria strigosa dead & & & 0.8 & & & & & & \\
\hline Diploria strigosa live & & & 0.9 & & & & & & \\
\hline Gorgonia sp. live & & & & 0.4 & & & & & \\
\hline Millepora alcicornis dead & & & & 0.6 & & & & & \\
\hline Montastrea annularis dead & & & & & & & 0.3 & & 0.3 \\
\hline Montastrea annularis live & & & & & -0.6 & & -0.7 & & \\
\hline Pavement & & 0.4 & & 0.5 & & & & & \\
\hline \multicolumn{10}{|l|}{ Porites astreoides dead } \\
\hline Porites porites dead & & & & & & & & & -0.8 \\
\hline Porites porites live & & & & & & & & -0.5 & -0.5 \\
\hline Sand & & & & & & 0.3 & & & \\
\hline Siderastrea radians dead & & & & 0.3 & -0.3 & -0.4 & & & \\
\hline \multicolumn{10}{|l|}{ Amphiroa rigida } \\
\hline Dicyota sp. & & -0.9 & & & & & & -0.8 & \\
\hline Halimeda incrassata & & & & & & & 0.4 & 0.4 & \\
\hline Padina jamaicensis & & & & 0.5 & & & & & \\
\hline \multicolumn{10}{|l|}{ Thalassia testudinum } \\
\hline Udotea sp. & & & & & & & 0.6 & 0.5 & \\
\hline No algae & & 0.9 & & & & & -0.8 & & \\
\hline Structural complexity of 0 & -0.3 & & & & & & & & \\
\hline \multicolumn{10}{|l|}{ Structural complexity of 1} \\
\hline Structural complexity of 2 & 0.6 & & & & & & & & \\
\hline Structural complexity of 3 & 0.8 & & & & & & & & \\
\hline Structural complexity of 4 & 0.7 & & & & & & & & \\
\hline Topographic complexity & 0.5 & & & & & & & & \\
\hline
\end{tabular}

uous reef sites of this study, while more similar to that of patch reefs. The lower slope of patch reefs, relative to continuous reefs, is likely explained by low habitat richness across all scales (discussed below), whereas continuous reefs demonstrate a greater increase in the number of species with area than is the case for many other studies. Why is this so? Three explanations are offered: an influence of the 3-dimensional nature of the reef systems; a consequence of the small range of spatial scales examined; or a result of a greater habitat richness, which in turn leads to the establishment of more species.

For most investigations of species-area relationships, a 2-dimensional (areal) plot is adequate because organisms are effectively restricted to the surface (bird communities are a clear exception). However, depending on the species, reef fish are not necessarily limited to a single horizontal layer but, instead, can be found anywhere within the water column. As such, this 3dimensional environment could result in a greater number of species added for every linear distance censused. In fact, Angermerier \& Schlosser (1989) found that, within streams, habitat volume was a better predictor of fish species richness than the 2-dimensional habitat area. Although the majority of fish observed in this study are found within $1 \mathrm{~m}$ of the substratum, it is quite possible that species were recorded beyond this $1 \mathrm{~m}$ height and thus influenced the slope to be greater relative to terrestrial counterparts.

An alternative, and more likely, explanation suggests that the slope of the species-area relationship may have been influenced by the range of areas sampled (Angermerier \& Schlosser 1989). In other words, large slopes associated with continuous reefs may have been the result of the relatively small spatial scales at which it was examined. Past studies have examined species-area relationships across scales ranging up to several thousands of square kilometers (Preston 1962a, b, Wade \& Thompson 1991, Androukaki \& Adamantopoulou 1992, Lawrey 1992, Oberdorff et al. 1995, Chiarucci 1996), whereas this study was limited to a maximum of $200 \mathrm{~m}^{2}$. For any given area, there are limits to the number of species present. Consequently, the increase in species with area cannot proceed indefinitely (i.e. species richness reaches an asymptotic level at large areas). Because large areas were not sampled in this study, an asymptotic species richness level was not achieved, resulting in a high slope. I would expect, however, that slopes might decline and 
more closely approximate those in other studies, as larger coral reef areas (larger spatial scales) are sampled. The analyses that included replicates of 100 and $200 \mathrm{~m}^{2}$ to form replicates of 1000, 2000, 3000, 4000 and $5000 \mathrm{~m}^{2}$ support this conclusion (i.e. slopes declined; Fig. 3). At approximately $2 \mathrm{~km}^{2}$, an asymptote began to form, which revealed an upper limit of approximately 74 coral reef fish species for communities of St. Croix. Even so, the average slope was still relatively high (0.41) compared to that of the majority of terrestrial and freshwater studies. Since 118 species were observed in over $9 \mathrm{~km}^{2}$ of censused reef, it is likely that the species-area curves will not completely plateau until at least this size area is censused.

Finally, the habitat diversity hypothesis has been regarded as an important hypothesis used to understand species-area relationships, and it is used here to explain why differences exist between slopes of patch and continuous reef species-area curves. Rosenzweig (1995) suggested that the number of species in an area was likely related to that area's habitat richness, since areas of greater richness offer new niches for colonizing species. Thus, areas with greater habitat richness should, according to this hypothesis, have more species per unit area, resulting in steeper slopes. Larger slopes may result from higher levels of habitat patchiness, which offer shelter to different species (Roth 1976), whereas lower slopes may result from smaller areas being more heterogeneous (relative to larger areas), and thus new species are not included with increasing sample size (Western \& Ssemakula 1981). This argument could be used to explain why patch reefs had significantly more species at smaller spatial scales (intercept) than continuous reefs, and yet, overall, the increase in species with area was far less (Fig. 4). Indeed patch reef microhabitat and algae/seagrass richness at the smallest scale (intercept) were 40 and $31 \%$ greater, respectively, than those for continuous reefs (Fig. 5), yet slopes of the same regressions were 43 and $98 \%$ greater, respectively, for continuous reefs. Therefore at larger patch reefs there was not a significant increase in the habitat richness, relative to that at smaller patches, which could negatively influence the presence of species if in fact fish species richness and habitat richness were strongly positively correlated.

In order to determine whether habitat richness explains a significant amount of variation in the numbers of species among patch and continuous reefs, separate investigations were conducted. These analyses indicated that the number of fish species on patch and continuous reefs were influenced by similar habitat characteristics, although to varying degrees (Tables 2 \& 3). Regression models indicated that species richness for both patch and continuous reefs was influenced by microhabitat richness. However, habitat richness, overall, was lower in patch reefs than in continuous reefs (see Fig. 5), which may account for the enhanced ability of microhabitat richness to explain species richness on continuous versus patch reefs. This observation indicates that factors not quantified here play a more important role in determining the number of species on patch reefs. In addition, these results suggest that reef fish species-area relationships, from continuous reefs, can be explained, to a degree, by the habitat diversity hypothesis. However, because the regressions included data that consisted of several spatial scales, it is likely that the relationship between species richness and habitat richness is an artifact of strong relationships with area (i.e. random placement hypothesis). Clearly, the specific role that area and habitat characteristics play in structuring reef fish assemblages needs to be determined to truly understand species-area relationships on continuous coral reefs.

In this study on species-area relationships within reef fish systems, I have found that richness of reef fish assemblages of St Croix, US Virgin Islands was positively related to the size of reef area for all censused sites. However, species-area relationships of patch and continuous reefs differed, likely owing to differences in habitat characteristics. Again, continuous reef areas, of greater habitat richness, contained more fish species per area than less habitat-rich patch reefs. A comparison between species-area relationships of terrestrial and marine systems indicated that differences in their slopes likely were due to the limited range of spatial scales sampled for this reef system. Moreover, since strong species-area relationships were observed within this reef system, terrestrial hypotheses of this phenomena, such as the random placement hypothesis and habitat diversity hypothesis (see Connor \& McCoy 1979), should be adopted and more closely examined in an aquatic setting in order to better understand what influences reef fish assemblages with area.

Acknowledgements. Special thanks to Dr P. F. Sale for support and constructive comments throughout this work, and to officers of the National Park Service, Buck Island Reef National Monument, St Croix, US Virgin Islands for assistance. A portion of this research was conducted at Buck Island Reef National Monument under permit \# 99005. Thanks to K. Hogan, Dr J. Lovett-Doust, Dr S. Ludsin and Dr C. Rodrigues for advice and support. This research was supported by NSERC grant \# OGP0154284 awarded to Dr P. F. Sale.

\section{LITERATURE CITED}

Abele LG, Patton WK (1976) The size of coral heads and the community biology of associated decapod crustaceans. J Biogeogr 3:35-47 
Anderson MJ (1998) Effects of patch size on colonisation in estuaries: revisiting the species-area relationship. Oecologia 123:87-98

Androukaki E, Adamantopoulou S (1992) A species-area relationship in the avifauna of northern sporades (Aegean, Greece). Biol Gallo-hellenica 19:37-44

Angermerier PL, Schlosser IJ (1989) Species area relationship for stream fishes. Ecology 70:1450-1462

Arrhenius O (1921) Species and area. J Ecol 9:95-99

Baldi A, Kisbenedek T (1999) Orthopterans in small steppe patches: an investigation for the best-fit model of the species-area curve and evidences for their non-random distributions in the patches. Acta Oecologica 20:125-132

Bell JD, Galzin R (1984) Influence of live coral cover on coral reef fish communities. Mar Ecol Prog Ser 15:265-274

Buckley RC (1985) Distinguishing the effects of area and habitat type on island plant species richness by separating floristic elements and substrate types and controlling for island isolation. J Biogeogr 12:527-535

Buys HM, Maritz JS, Boucher C, Van Der Walt JJA (1994) A model for species area relationships in plant communities. J Veg Sci 5:63-66

Caselle J, Warner R (1996) Variability in recruitment of coral reef fishes: the importance of habitat at two spatial scales. Ecology 77:2488-2504

Chemengich BT (1993) Ecological relationships between agromyzidae feeding on leguminous plants and species area effects in Kenya. Insect Sci Appl 14:603-609

Chiarucci A (1996) Species diversity in plant communities on ultramafic soils in relation to pine afforestation. J Veg Sci $7: 57-62$

Connor EF, McCoy ED (1979) The statistics and biology of the species area relationship. Am Nat 113:791-833

Danell K, Lundberg P, Niemela P (1996) Species richness in mammalian herbivores: patterns in the boreal zone. Ecography 19:404-409

Dunn CP, Loehle C (1988) Species-area parameter estimation: testing the null model of lack of relationship. J Biogeogr 15:721-728

Durrett R, Levin S (1996) Spatial models for species area curves. J Theor Biol 179:119-127

Falkner MB, Stohlgren YJ (1997) Evaluating the contribution of small national park areas to regional biodiversity. Nat Areas 17:324-330

Gasnier N, Cabaret J, Chartier C, Reche B (1997) Species diversity in gastrointestinal nematode communities of dairy goats: species area and species climate relationships. Vet Res 28:55-64

Gleason H (1922) On the relation between species and area. Ecology 3:158-162

Hart DD, Horwitz RJ (1991) Habitat diversity and the speciesarea relationship: alternative models and tests. In: Bell SS, McCoy ED, Mushinsky HR (eds) Habitat structure: the physical arrangement of objects in space. Chapman and Hall, London, p 47-68

He F, Legendre P (1996) On species-area relations. Am Nat 148:719-737

Jennings S, Boulle DP, Polunin NVC (1996) Habitat correlates of the distribution and biomass of Seychelles' reef fishes. Environ Biol Fish 46:15-25

Johnson GD, Patil GP (1995) Estimating statewide species richness of breeding birds in Pennsylvania. COENOSES 10:81-87

Jones G, Syms C (1998) Disturbance, habitat structure and the ecology of fishes on coral reefs. Aust J Ecol 23:287-297
Lawesson JE, deBlust G, Grashof C, Firbank L and 4 others (1998) Species diversity and area-relationships in Danish beech forests. Forest Ecol Manage 106:235-245

Lawrey JD (1992) Natural and randomly-assembled lichen communities compared using the species-area curve. Bryologist 95:137-141

MacArthur RH, Wilson EO (1967) The theory of island biogeography. Princeton University Press, Princeton

McClanahan TR (1994) Kenyan coral reef lagoon fish: effects of fishing, substrate complexity, and sea urchins. Coral Reefs 13:231-241

McGuinness KA (1984) Equations and explanations in the study of species-area curves. Biol Rev 59:423-440

Morrison L (1997) The insular biogeography of small Bahamian cays. J Ecol 5:441-454

Nilsson SG, Bengtsson J, As S (1988) Habitat diversity or area per se? Species richness of woody plants, carabid beetles and land snails on islands. J Anim Ecol. 57:685-704

Oberdorff T, Guegan J, Hugueny B (1995) Global scale patterns of fish species richness in rivers. Ecography 18:345-352

Palmer MW, White PS (1994) Scale dependence and the species area relationship. Am Nat 144:717-740

Peake AJ, Quinn GP (1993) Temporal variation in speciesarea curves for invertebrates in clumps of an intertidal mussel. Ecography 16:269-277

Preston FW (1962a) The canonical distribution of commonness and rarity: Part I. Ecology 43:185-215

Preston FW (1962b) The canonical distribution of commonness and rarity: Part II. Ecology 43:410-431

Rejmanek M, Rosen E (1992) Influence of colonizing shrubs on species-area relationships in alvar plant communities. J Veg Sci 3:625-630

Roberts C, Ormond RFG (1987) Habitat complexity and coral reef fish diversity and abundance on Red Sea fringing reefs. Mar Ecol Prog Ser 41:1-8

Rosenzweig ML (1995) Species diversity in space and time. Cambridge University Press, Cambridge, p 170-190

Roth R (1976) Spatial heterogeneity and bird species diversity. Ecology 57:773-782

Santelices B, Hoffmann AJ, Aedo D, Bobadilla M, Otaiza R (1995) A bank of microscopic forms on disturbed boulders and stones in tide pools. Mar Ecol Prog Ser 129:215-228

Schoener A, Schoener TW (1981) The dynamics of the species-area relation in marine fouling systems: 1. Biological correlates of changes in the species-area slope. Am Nat 118:339-360

Simberloff DS (1976) Experimental zoogeoraphy of islands: effects of island size. Ecology 57:629-648

Singh JS, Bourgeron P, Lauenroth WK (1996) Plant species richness and species-area relations in a shortgrass steppe in Colorado. J Veg Sci 7:645-650

Statistica II (1995) Statistics II, 2nd edn. Statistica for Windows, Vol 3. Statsoft, Tulsa, OK

Stohlgren TJ, Chong GW, Kalhkan MA, Schell LD (1997) Multiscale sampling of plant diversity: effects of minimum mapping unit size. Ecol Appl 7:1064-1074

Tabachnick B, Fidell L (1996) Using multivariate statistics, 3rd edn. HarperCollins, New York

Wade GL, Thompson RL (1991) The species-area curve and regional floras. Trans Ky Acad Sci 52:21-26

Western D, Ssemakula J (1981) The future of the savannah ecosystems: ecological islands or faunal enclaves? Afr J Ecol 19:7-19

Zar JH (1996) Biostatistical analysis, 3rd edn. Prentice Hall, Upper Saddle River, NJ

Submitted: November 13, 2000; Accepted: November 20, 2001 Proofs received from author(s): April 29, 2002 